\title{
4-Methylumbelliferone treatment and hyaluronan inhibition as a therapeutic strategy in inflammation, autoimmunity, and cancer
}

\section{Nadine Nagy $^{1}{ }^{*}$, Hedwich F. Kuipers ${ }^{1}$, Adam R. Frymoyer ${ }^{2}$, Heather D. Ishak ${ }^{1}$, Jennifer B. Bollyky ${ }^{3}$, Thomas N. Wight ${ }^{4}$ and Paul L. Bollyky ${ }^{1}$}

${ }^{1}$ Division of Infectious Diseases and Geographic Medicine, Department of Medicine, Stanford University School of Medicine, Stanford, CA, USA

${ }^{2}$ Department of Pediatrics, Stanford University School of Medicine, Stanford, CA, USA

${ }^{3}$ Department of Pediatrics and Systems Medicine, Stanford University School of Medicine, Stanford, CA, USA

${ }^{4}$ Matrix Biology Program, Benaroya Research Institute, Seattle, WA, USA

\section{Edited by:}

David Naor, Hebrew University of Jerusalem, Israel

\section{Reviewed by:}

Kaylee Schwertfeger, University of Minnesota, USA

Rashmin C. Savani, University of Texas Southwestern Medical Center, USA

Feng Gao, Shanghai 6th People's Hospital, China

\section{*Correspondence:}

Nadine Nagy, Division of Infectious Diseases and Geographic Medicine, Department of Medicine, Stanford University School of Medicine, 300 Pasteur Drive, Stanford, CA 94305-5107, USA

e-mail:nnagy@stanford.edu
Hyaluronan $(\mathrm{HA})$ is a prominent component of the extracellular matrix at many sites of chronic inflammation, including type 1 diabetes (T1D), multiple sclerosis, and numerous malignancies. Recent publications have demonstrated that when HA synthesis is inhibited using 4-methylumbelliferone (4-MU), beneficial effects are observed in several animal models of these diseases. Notably, 4-MU is an already approved drug in Europe and Asia called "hymecromone" where it is used to treat biliary spasm. However, there is uncertainty regarding how 4-MU treatment provides benefit in these animal models and the potential long-term consequences of $\mathrm{HA}$ inhibition. Here, we review what is known about how HA contributes to immune dysregulation and tumor progression. Then, we review what is known about 4-MU and hymecromone in terms of mechanism of action, pharmacokinetics, and safety. Finally, we review recent studies detailing the use of 4-MU to treat animal models of cancer and autoimmunity.

Keywords: hyaluronan, 4-methylumbelliferone, hymecromone, immune diseases, cancer
There have been an increasing number of studies utilizing 4methylumbelliferone (4-MU) to inhibit hyaluronan (HA) for either experimental or pre-clinical purposes. These studies are notable because of the central role HA plays in many disease processes, including inflammation and cancer progression, and because of the potential utility in repurposing 4-MU, a drug already used in humans for other indications, to treat these diseases.

This review will first briefly summarize the known contributions of HA to inflammation and cancer progression. Then, it will describe the chemistry and pharmacokinetics of 4-MU, particularly in regards to its inhibition of HA production. Finally, it will examine the available clinical data on the use of 4-MU treatment in humans and summarize the available data on safety and efficacy in animal models.

\section{HYALURONAN}

HA is an extracellular matrix (ECM) glycosaminoglycan (GAG). It has many roles in normal tissue function and development, including providing support and anchorage for cells, facilitating cell-cell signaling, and facilitating cell movement and migration (1-4).

HA is synthesized by three, independently regulated HA synthase (HAS) proteins. These generate predominantly high molecular weight-HA (HMW-HA) of between $2 \times 10^{5}$ and $2 \times 10^{6} \mathrm{Da}$ (5). These enzymes lengthen HA by repeatedly adding glucuronic acid and $\mathrm{N}$-acetyl-glucosamine to the nascent polysaccharide as it is extruded through the cell membrane into the extracellular space (4). HA in circulation is rapidly degraded while HA bound to proteins and incorporated into tissues such as joints, basement membranes, and the vitreous of the eye is longer lived (5-8).

HA catabolism is mediated by endogenous hyaluronidases, by bacterial hyaluronidases, by mechanical forces, and by oxidative stress (9). This catabolism results in a continuum of different-sized HA polymers, including low molecular weight-HA (LMW-HA; <120 kDa) and, ultimately, in HA oligomers. One important factor in determining the longevity and size of HA are its interactions with HA-binding proteins, called hyaladherins that protect HA from catabolism and turnover. These include TNF-stimulated gene-6 (TSG-6) and inter- $\alpha$-inhibitor (I $\alpha$ I) (10, 11). Hyaladherins are thought to interact with HA in such a way as to promote the formation of macromolecular complexes that modulate leukocyte adhesion and activation, thus influencing the inflammatory response $(3,4,10)$.

The main receptors for HA are CD44 and RHAMM. Upon binding to HA, intracellular signaling pathways are activated; consequently, the receptors participate in a variety of cellular functions including lymphocyte activation and tumor metastasis.

HA levels are greatly elevated in injured tissues, with production increasing by as much as 80 -fold (4). Because HA is highly hygroscopic (12), this increased HA production is likely to drive edema at sites of injury. Consistent with this, HA has 
been implicated in vascular permeability changes (13), leukocyte adhesion and egress (14), and migration (15). HA can be organized into a variety of molecular architectures by forming cross-linked complexes with the above mentioned proteins, and can serve as ligands for leukocytes. Such interactions may trap the leukocytes and prevent eventual destruction of the tissue, as well as trap pro-inflammatory mediators (10). These ECM molecules may initiate a cascade of events that promote inflammation by attracting inflammatory cells and promoting their activation (16).

Along with the amount of HA, the size distribution of local HA polymers varies between healthy and inflamed tissues. Longer polymers of HMW-HA typically predominate in most tissues under steady-state conditions while, shorter, LMW-HA polymers predominate at sites of active inflammation $(2,17,18)$. In light of these associations, HA size has been called a natural biosensor for the state of tissue integrity (19).

These changes in the size of HA have functional consequences because of the differential impacts of HA polymers of different sizes on injury responses and homeostasis. HMW-HA, which predominates in healthy tissues, typically inhibits inflammation (20-22). Consistent with this, administration of HMW-HA is anti-inflammatory in lung injury models (23), collagen-induced arthritis (24), and a variety of other in vivo model systems (2529). The generally anti-inflammatory properties of HMW-HA may be mediated, in part, through interactions with the HA receptor CD44 [reviewed in Ref. (18)] and/or through hyaladherins known to bind HA, including TSG-6 and I $\alpha$ I (11, 30, 31).

LMW-HA, conversely, is thought to drive local inflammatory responses by acting as a pro-inflammatory "danger signal" or damage-associated molecular pattern (DAMP) through effects on Toll-like receptor (TLR) signaling $(3,32,33)$. LMW-HA promotes the activation and maturation of dendritic cells (DCs) (34), drives the release of pro-inflammatory cytokines such as IL-1 $\beta$, TNF- $\alpha$, IL-6, and IL-12 by multiple cell types (35-39), drives chemokine expression and cell trafficking $(40,41)$, and promotes proliferation $(42,43)$ and angiogenesis (44). In light of these and other data (45), it seems likely that LMW-HA and HA catabolism contribute to the perpetuation of inflammation in multiple tissues.

\section{HA IN CHRONIC INFLAMMATION}

Many chronic disease processes associated with unremitting inflammation are associated with prolonged increases in HA, including type 2 diabetes (T2D) $(46,47)$, liver cirrhosis (48), asthma, and other diseases (49-54). These conditions are typically associated with accumulations of LMW-HA [reviewed in Ref. (18)].

LMW-HA may also promote immune dysregulation at these sites. We have reported that LMW-HA inhibits the function of Foxp3+ regulatory T-cells (Treg) (38), a cell type that plays a major role in suppressing autoimmunity (55). Other TLR agonists are known to have similar effects on Treg (56).

Recently (57), we reported that autoimmune insulitis in autoimmune type 1 diabetes (T1D) was associated with isletspecific deposition of HA. Using human T1D tissue samples from cadaveric organ donors obtained through the Juvenile
Diabetes Research Foundation (JDRF) National Pancreatic Organ Donor (nPOD) program, we discovered that HA deposits were present in islets from recent-onset T1D donors but not in non-diabetic controls. These T1D-associated HA deposits were also associated with local alterations in hyaladherins, including reduced levels of intra-islet TSG- 6 and I $\alpha$ I and increases in mRNA of versican, a pro-inflammatory hyaladherin (57). We have made similar observations in animal models of autoimmune diabetes, including non-obese diabetic (NOD) mice (58) and DORmO mice. Together with recently published histologic and biochemical analyses by our group and others, of islet ECM in non-diabetic human and murine islets (59-62), these data implicated HA and the islet ECM in the onset of T1D.

Along with insulitis, HA is highly abundant within demyelinated lesions in multiple sclerosis (MS) and in experimental autoimmune encephalomyelitis (EAE) (63). It is produced by local astrocytes $(63,64)$, and is known to contribute to EAE by promoting the extravasation of leukocytes (65) and inhibiting oligodendrocyte maturation $(66,67)$. Lymphocyte infiltration into the CNS is known to precede HA production by astrocytes in EAE, suggesting that astrocytes may produce HA in response to inflammatory factors produced by lymphocytes $(63,64,68,69)$.

HA has also been implicated in other autoimmune diseases, including rheumatoid arthritis $(70,71)$, lupus (72), Sjögren's syndrome (73), and Hashimoto's thyroiditis (74). There is further evidence that targeting HA receptors, including CD44, may be beneficial in several animal models of autoimmunity, including the NOD mouse model of autoimmune diabetes and the collageninduced arthritis model of rheumatoid arthritis (75-77), though these effects may result from effects on lymphocyte trafficking or apoptosis rather than effects on the local ECM milieu.

\section{HA IN CANCER}

There is extensive communication between the tumor microenvironment and cancer cells $(78,79)$. This communication is thought to govern critical cellular processes in metastasis, including angiogenesis, proliferation, and stimulation of tissue-degrading proteases (80). Consistent with this, in vivo and in vitro data from different origins and various malignancy grades revealed a positive correlation between tumor aggressiveness and stromal HA expression (81-83).

Different expression patterns of HASes are seen during tumor progression. Aggressive ovarian and breast cancer cells express high levels of HA synthase 2 (HAS2) and lower levels of HA synthase 3 (HAS3) compared to non-aggressive cancer cells $(84,85)$. Indeed, HAS expression levels are inversely correlated with breast cancer staging grades and patient survival (86). HAS expression patterns may be somewhat cancer specific; for example, metastatic prostate and colon cancer express higher levels of HAS3 than HAS2. HA synthase 1 (HAS1) on the other hand was expressed only at very low levels in these tumors $(87,88)$.

HA forms inter- and intra-molecular organizations, creating a viscous milieu well suited for tumor growth and metastasis. This HA-rich tumor matrix provides structural integrity, maintenance of homeostasis, release of growth factors, cytokines, and nutrients 
essential for proliferation (10). HA plays an important role in cancer in intracellular signaling cascades associated with tumor growth (89), tumor cell adhesion (90), neovascularization (9193), and metastasis (90). Many of these pro-tumorigenic effects are attributable to HA fragments.

Conversely, HMW-HA was recently implicated in the inhibition of tumor progression (94). Tian et al. found that naked mole-rat fibroblasts secrete HMW-HA, which is over five times larger than human or mouse HA. This HMW-HA accumulates in naked mole-rat tissues. Interestingly, once HMW-HA is removed by either knocking down HAS2 or overexpressing hyaluronidase 2 (HYAL2), the naked mole-rat cells become susceptible to malignant transformation and form tumors.

$\mathrm{HA}$ is also known to influence the susceptibility of tumors to chemotherapeutic agents (95). HA-evoked anti-cancer drug resistance may be of a physico-mechanical nature as a dense ECM limits the delivery and distribution of therapeutic agents (96) and enzymatic depletion of HA is being explored as a means to improve drug delivery (97). Indeed, hyaluronidase, an enzyme that degrades HA, has been used in tumor therapy in combination with chemotherapeutic agents for over two decades (98).

Another reported approach to facilitate the delivery of chemotherapeutic agents through HA is to use the large volumetric domain of HA to entrain small chemotherapeutic drugs within the HA matrix. The resultant HA/drug formulation accumulates in the microvasculature of the tumor, forming a microembolism that increases drug retention at the tumor site and allows for active tumor uptake through HA receptors (99). As a result, a Phase II clinical trial of specific HA formulations of three anti-cancer drugs have been undertaken (100).

Taken together, these data suggest that HA may create a permissive environment for tumor growth and metastasis.

\section{4-METHYLUMBELLIFERONE}

In light of these contributions of HA to inflammation, autoimmunity, and to tumor growth and metastasis, there has been great interest in identifying pharmacologic tools to inhibit HA synthesis. One agent that has received much attention is 4-MU (Figure 1).

4-MU is a derivative of coumarin. Other coumarin derivatives, phenprocoumon (Marcumar ${ }^{\circledR}$ ) and warfarin (Coumadin ${ }^{\circledR}$ ), are used in preventive medicine to reduce cardiovascular events due to its anticoagulatory mechanism. Coumarin hydroxylated in position seven is known as umbelliferone and is a natural molecule in plants worldwide. Known representatives of umbellifera are lovage (Levisticum officinale) and chamomile (Matricaria recutita).

4-MU is umbelliferone methylated at position four. It has the IUPAC name 7-hydroxy-4-methylcoumarin and the international free name (INN) hymecromone. It has the molecular formula $\mathrm{C}_{10} \mathrm{H}_{8} \mathrm{O}_{3}$, a molecular weight of $176.2 \mathrm{kDa}$, the CAS number is $90-33-5$, and a pKa of 7.79. The melting point of 4-MU is $194-$ $195^{\circ} \mathrm{C}$. 4-MU is soluble in methanol with heating, DMSO, and in glacial acetic acid. It is slightly soluble in ether or chloroform and practically insoluble in water.

4-MU is known for its fluorescent properties and has an excitation wavelength of $380 \mathrm{~nm}$ and an emission wavelength of $454 \mathrm{~nm}$ in water. It is colorless at $\mathrm{pH} 7.0$ and exhibits a blue fluorescence at $\mathrm{pH}$ 7.5. In light of these properties, it has been used extensively as a $\mathrm{pH}$-sensitive fluorescent indicator in multiple experimental settings.

\section{4-MU-MEDIATED INHIBITION OF HA PRODUCTION}

The other major experimental use of 4-MU is for HA inhibition. 4-MU has been shown to inhibit HA production in multiple cell lines and tissue types both in vitro and in vivo (101-108).
A<smiles>Cc1cc(=O)oc2cc(O)ccc12</smiles><smiles>Cc1cc(=O)oc2cc(OS(=O)(=O)[O-])ccc12</smiles><smiles>Cc1cc(=O)oc2cc(OC3OC(C(=O)O)[C@@H](O)[C@H](O)[C@H]3O)ccc12</smiles>

4-methylumbelliferone

4-methylumbelliferyl sulfate

\section{4-methylumbelliferyl glucuronide}

FIGURE 1 | Molecular structure of 4-MU and its metabolites. (A) 4-Methylumbelliferone (4-MU), (B) 4-methylumbelliferyl sulfate (4-MUS), (C) 4-methylumbelliferyl glucuronide (4-MUG). 
4-MU is thought to inhibit HA production in at least two ways. First, 4-MU is thought to function as a competitive substrate for UDP-glucuronosyltransferase (UGT), an enzyme involved in HA synthesis (106). HA is produced by the HAS1, HAS2, and HAS3 from the precursors UDP-glucuronic acid (UDP-GlcUA) and UDP- $N$-acetyl-glucosamine (UDP-GlcNAc). These are generated by the transfer of an UDP-residue to $N$-acetylglucosamine and glucuronic acid via the UGT. The availability of UDP-GIcUA and UDP-GlcNAc thereby controls HA synthesis (109). However, when 4-MU is present, it covalently binds through its hydroxyl group at position four to glucuronic acid via the UGT. As a consequence, the concentration of UDP-GlcUA declines in the cytosol and HA synthesis is reduced (Figure 2). 4-MU thereby reduces the UDP-GlcUA content inside the cells and inhibits HA synthesis.

Second, 4-MU reduces expression of HAS mRNA expression (105) as well as mRNA for UDP-glucose pyrophosphorylase and dehydrogenase (110). It is unclear how this second mechanism works or how selective it is for these mRNAs.

\section{4-MU EFFECTS ON OTHER GAGS}

4-MU is commonly described as a specific inhibitor of HA synthesis. However, its impact on other GAGs has not been definitively established, to our knowledge.

It was recently reported that 4-MU exerts at least some of its actions via regulation of UDP-glucose dehydrogenase (UGDH), a key enzyme required for both $\mathrm{HA}$ and sulfated-glycosaminoglycan (sGAG) production (111). However, other GAGs, such as chondroitin and heparin sulfates, were less sensitive to UDP-GlcUA deficiency. This was suggested to be because they are synthesized in the Golgi apparatus, which has transporters with a very high affinity that pump in UDP sugars from the cytosol that might render inhibition by a competitive substrate such as 4-MU less efficient. In contrast, HA is synthesized at the cytoplasmic membrane.

\section{4-MU EFFECTS ON TUMORS AND CANCER CELLS}

The first described use of 4-MU in the context of HA was in 1995 when Nakamura et al. published their study about 4-MU in human skin fibroblasts (112). The postulated 4-MU mechanism was described years later in 2004 by Kakizaki and his group (106).

By far, the greatest experience with 4-MU is in cancer cell lines and in vivo models. In 2006, the first in vivo study investigating the effect of 4-MU on pancreatic cancer was published (113). More in vitro and in vivo studies have followed on this subject (114129). These are detailed in Table 1 . The consensus of these studies is that 4-MU inhibits the proliferation, migration, and invasion of multiple cancer cell types, both in vitro and in vivo.

Most of these effects are consistent with what is known about the physiologic roles of HA in normal growth and differentiation and how many tumors establish HA-rich matrices to promote their own growth and metastasis. For example, consistent with HA's role in cell survival pathways, 4-MU treatment is associated with growth arrest and apoptosis of tumor cells (120). Indeed, the apoptotic effect of 4-MU on smooth muscle cells could be rescued with exogenous HA (139). Consistent with the established role of $\mathrm{HA}$ in angiogenesis, 4-MU treatment is reported to suppress the new blood vessel growth required for metastases $(103,110)$.

However, it is not obvious that all of the effects of 4-MU treatment are directly related to HA inhibition. For example, 4-MU was recently reported to inhibit growth of an ovarian tumor cell line via suppression of thymidine phosphorylase (TP) mRNA (127).

In summary, the use of 4 -MU to inhibit cancer progression is an active frontier in oncology research, with extensive data in animal models and in vitro cell lines supporting further investigation. However, while one can be optimistic about the potential for adjunctive benefit of 4-MU in cancer therapy, much remains unknown and crucial human clinical studies have yet to be done.

\section{4-MU EFFECTS ON INFLAMMATION AND AUTOIMMUNITY}

There have been more limited investigations into the impact of 4-MU and HA synthesis inhibition in inflammation and autoimmunity. McKallip et al. reported that 4-MU treatment prevented lung injury and reduced inflammatory cytokine levels in mouse models of staphylococcal enterotoxin-mediated (135) and lipopolysaccharide-mediated acute lung injury (136). 4-MU has also been used to inhibit HA production by several
$\mathrm{N}$-acetyl-glucosamine

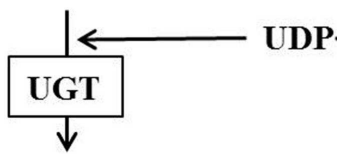

UDP-N-acetyl-glucosamine

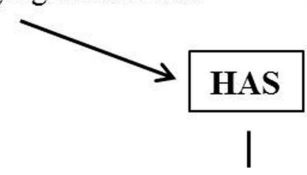

UDP-glucuronic acid

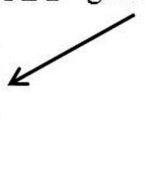
$\mathrm{N}$-acetyl-glucosamine- $\beta(1,4)$ glucuronic acid

hyaluronan

glucuronic acid
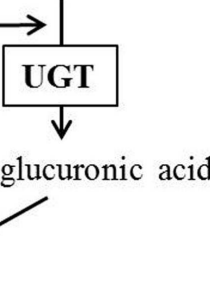

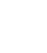


Table 1 | List of experimental studies using 4-MU, broken down by disease type.

\begin{tabular}{|c|c|c|}
\hline Cancer & Inflammation & Autoimmunity \\
\hline $\begin{array}{l}\text { Pancreatic cancer } \\
(113-115)\end{array}$ & $\begin{array}{l}\text { Non-infectious } \\
\text { inflammation (130-132) }\end{array}$ & $\begin{array}{l}\text { CNS autoimmunity } \\
\text { (133) }\end{array}$ \\
\hline Prostate cancer (134) & $\begin{array}{l}\text { Infectious inflammation } \\
(135,136)\end{array}$ & $\begin{array}{l}\text { Autoimmune } \\
\text { arthritis (70) }\end{array}$ \\
\hline \multicolumn{3}{|l|}{ Skin cancer $(107,116-118)$} \\
\hline \multicolumn{3}{|l|}{ Esophageal cancer (129) } \\
\hline \multicolumn{3}{|l|}{ Breast cancer (119-121) } \\
\hline \multicolumn{3}{|l|}{ Liver cancer $(122,123)$} \\
\hline \multicolumn{3}{|l|}{$\begin{array}{l}\text { Bone cancer/metastases } \\
(126,128,137,138)\end{array}$} \\
\hline \multicolumn{3}{|l|}{ Leukemia $(124,125)$} \\
\hline Ovarian cancer (127) & & \\
\hline
\end{tabular}

human pathogens and their interactions with human cells in vitro $(140,141)$.

4-MU has also been shown to have protective effects on noninfectious inflammation, including renal ischemia and reperfusion (130), and airway inflammation secondary to cigarette smoke (131). 4-MU was shown to restore normoglycemia and promote insulin sensitivity in obese, diabetic mice via increased production of adiponectin (132).

4-MU has also been reported to ameliorate disease in a limited number of mouse models of autoimmune disease. Specifically, 4-MU treatment was beneficial in the collagen-induced arthritis model where it improved disease scores and reduced expression of matrix metalloproteases (MMPs) (70). More recently, 4-MU treatment was demonstrated to prevent and treat disease in the EAE model where it increased populations of regulatory T-cells and polarized T-cell differentiation away from pathogenic, Thelper $1 \mathrm{~T}$-cell subsets and toward non-pathogenic T-helper 2 subsets (133).

These effects point toward a potential role for 4-MU in immune modulation. We have reported that 4-MU treatment prevented cell-cell interactions required for antigen presentation (108) and others have described inhibitory effects on T-cell proliferation (102). These effects are consistent with established roles for HA and its receptors in T-cell proliferation, activation, and differentiation $(3,142,143)$. These data also align well with the known effects of 4-MU in lymphoma studies $(124,125)$.

One pressing question is why $4-\mathrm{MU}$ is anti-inflammatory in multiple systems whereas HA itself has both pro-and antiinflammatory attributes. One hypothesis is that 4-MU may lead to a preponderance of HMW-HA polymers, with typically anti-inflammatory properties over HA fragments, with typically pro-inflammatory properties. This model assumes that loose HA fragments are more readily cleared than HMW-HA, which is more likely to be integrated into stable matrices and perhaps therefore less subject to rapid turnover. A related notion is that most of the increase in HA production that occurs at times of inflammation is pro-inflammatory in ways that HA produced at times of homeostasis is not. These differences could be mediated either at the level of the different HASes or via cotemporaneous production of hyaladherins. These hypotheses remain to be tested.

There are also indications that 4-MU treatment may make some models of inflammation worse. For example, 4-MU treatment was also associated with worse atherosclerosis in ApoE-deficient mice fed a high-fat diet (104). It is tempting to speculate that HA plays roles in barrier function in some tissues such that its loss leads to enhanced exposure to bacteria or inflammatory mediators.

\section{HYMECROMONE}

4-MU is already an established therapeutic currently used in humans. Called "hymecromone," it is used in multiple countries mainly for its choleretic and biliary antispasmodic activity (144147). Despite being a coumarin derivative, hymecromone does not possess anticoagulant properties. In Europe, hymecromone is an approved drug for use in humans for biliary dyskinesia (original European Union reference date 07/27/1960). For example, in Italy, hymecromone is marketed as a generic named Cantabilin ${ }^{\circledR}$ with a current marketing authorization via the Italian Medicines Agency (AIC no. 02130002) [“Cantabilin ${ }^{\circledR}$ (hymecromone Tablets) (Italian Package Insert)” 2013].

\section{CLINICAL EXPERIENCE WITH HYMECROMONE (4-MU)}

The typical approved dosing regimen for adults is $300-800 \mathrm{mg}$ three times/day by mouth ( $900-2400 \mathrm{mg} /$ day). It is generally available as a tablet with dose strengths of 300-400 mg. Hymecromone is currently not approved for any indication in the U.S., and therefore requires an Investigational New Drug (IND) application from the Food and Drug Administration (FDA) for clinical studies conducted in the U.S.

Several clinical trials in humans, including randomized placebo-controlled, have been published on hymecromone and all demonstrated excellent safety during short-term administration of approved doses (148-154) (Table 2). Taken together, at least 182 patients have been exposed in clinical trials and no serious adverse events from hymecromone were reported. The longest reported duration of administration of hymecromone was a multiple-dose study of oral administration of hymecromone at $1200 \mathrm{mg} /$ day (400 mg three times/day) for 3 month in 20 participants with biliary dyskinesia (152). The tolerability and safety of longer durations of chronic administration is not known, yet this will be necessary to formally establish given the potential need for chronic long-term treatment duration as a therapy in inflammatory or autoimmune conditions.

Overall, the most common side effects during hymecromone treatment are diarrhea or other mild gastrointestinal symptoms ["Cantabilin ${ }^{\circledR}$ (hymecromone tablets) (Italian Package Insert)" 2013]. The diarrhea occurs in $1-10 \%$ of patients and appears to be dose-dependent. One study reported a dose of $2400 \mathrm{mg} /$ day ( $800 \mathrm{mg}$ three times/day) continued for more than 7 days would be expected to result in unacceptable diarrhea. However, this was a study in patients who had undergone bile duct surgery including insertion of a T-drain into the common bile duct. Therefore, whether patients with a normal biliary system would experience the same level of diarrhea at this dose is unknown. 
Table 2 | Clinical trials using hymecromone (4-MU) in humans

\begin{tabular}{|c|c|c|c|c|c|c|}
\hline Reference & Patient type & Study type & $n$ & Dose & Duration & Adverse events/notes \\
\hline (153) & $\begin{array}{l}\text { Patients requiring } \\
\text { cholecystectomy, } \\
\text { age }>14\end{array}$ & $\begin{array}{l}\text { Double-blind, randomized, } \\
\text { placebo-controlled }\end{array}$ & 25 & $\begin{array}{l}2400 \mathrm{mg} / \text { day } \times 7.5 \text { days } \\
\text { then } 1200 \mathrm{mg} \times 7 \text { days }\end{array}$ & 2 weeks & $\begin{array}{l}\text { Decreased drain output and } \\
\text { need for post-op analgesics, } \\
\text { two pts with mild headaches } \\
\text { in treatment group, three with } \\
\text { decreased appetite and } \\
\text { diarrhea in placebo group }\end{array}$ \\
\hline (149) & $\begin{array}{l}\text { Post-cholecystectomy } \\
\text { dyspepsia, age >60, } \\
\text { mean } 58.5 \text { years }\end{array}$ & $\begin{array}{l}\text { Double-blind, randomized, } \\
\text { placebo-controlled }\end{array}$ & 15 & 600 mg BID & 3 weeks & N/A \\
\hline (152) & Biliary dyskinesia & $\begin{array}{l}\text { Randomized controlled trial } \\
\text { vs. tiropramide } 300 \mathrm{mg}\end{array}$ & 20 & 1200 mg daily & 3 months & N/A \\
\hline (149) & $\begin{array}{l}\text { Patients requiring } \\
\text { cholecystectomy, age } \\
\text { 29-84 }\end{array}$ & $\begin{array}{l}\text { Placebo-controlled, } \\
\text { randomized }\end{array}$ & 13 & 1600 mg/day & 3 weeks & N/A \\
\hline$(155)$ & Healthy, age 21-35 & Pharmacokinetics & 8 & $\begin{array}{l}400 \text { mg IV, } 800 \text { mg IV, } \\
600 \text { mg PO solution, } \\
1200 \text { mg PO solution, } \\
1200 \text { mg tablets }\end{array}$ & Once & N/A \\
\hline$(150)$ & Healthy, age 22-30 & $\begin{array}{l}\text { Prospective, double-blind, } \\
\text { randomized cross-over study }\end{array}$ & 20 & $400 \mathrm{mg}$ IV & $\begin{array}{l}\text { Once, after } \\
\text { meal }\end{array}$ & N/A \\
\hline (148) & Healthy & $\begin{array}{l}\text { Placebo-controlled, } \\
\text { multicenter, randomized }\end{array}$ & 61 & $\begin{array}{l}600 \mathrm{mg} \text { with lunch, } \\
600 \mathrm{mg} \text { with dinner }\end{array}$ & 2 weeks & N/A \\
\hline (154) & Healthy, age 20-37 & $\begin{array}{l}\text { 4-methylumbelliferone PO } \\
\text { and IV }\end{array}$ & 20 & $800 \mathrm{mg} \times 1(\mathrm{PO}$ and IV) & $\begin{array}{l}\text { Once, with } \\
\text { meal }\end{array}$ & N/A \\
\hline
\end{tabular}

Also of value from a safety perspective is a single dose study in healthy volunteers given as an intravenous dose of 400 and $800 \mathrm{mg}$ (145). Side effects other than those related to intravenous (IV) injection for the $400 \mathrm{mg}$ IV dose included minor dizziness and nausea (four of eight subjects) and "cold sweat" for $5 \mathrm{~min}$ (two of eight subjects). After the $800 \mathrm{mg}$ IV dose, side effects reported included "bad after taste" (one of six subjects), nausea and dizziness (three of six subjects), and emesis (two of six subjects). This safety data is of significance as the bioavailability after oral dosing is $<3 \%$. Therefore, the systemic exposures after these IV doses were substantially higher than the exposure after typical oral doses. While the safety data at these higher exposures after IV dosing are severely limited given only single dose exposure, it may hint at the tolerability of higher oral doses of hymecromone in humans, which may be necessary for new indications of the drug if higher systemic exposures are required. The overall safety of hymecromone is further supported by animal data noted in the Italian Medicines Agency "package insert" which notes, "acute toxicity has proved to be very low: the LD50, for oral administration is $7593 \mathrm{mg} / \mathrm{kg}$ in mice and $6220 \mathrm{mg} / \mathrm{kg}$ in rats. Protracted oral administration in the range of $800-2400 \mathrm{mg} / \mathrm{kg} /$ day for 3 months and in the rat $400-1000 \mathrm{mg} / \mathrm{kg} /$ day for 4 months, has shown excellent tolerability..." ["Cantabilin ${ }^{\circledR}$ (hymecromone tablets) (Italian Package Insert)" 2013]. Contraindications to taking hymecromone include pregnancy and lactation given the lack of safety data in these groups ["Cantabilin ${ }^{\circledR}$ (hymecromone tablets) (Italian Package Insert)” 2013].

Taken together, the clinical experience to date suggests hymecromone is a safe and well-tolerated oral medication. The safety of oral hymecromone doses as high as $2400 \mathrm{mg} /$ day and treatment durations as long as 3 months have been demonstrated in humans and can serve as a benchmark for early stage clinical trials exploring new indications.

\section{CLINICAL PHARMACOLOGY OF HYMECROMONE}

Hymecromone is extensively metabolized and $<1 \%$ of a given dose is excreted unchanged in the urine $(155,156)$. Metabolism of the drug occurs via conjugation to either a glucuronic acid, 4-MUG, or a sulfate (4-MUS) (Figure 1). The glucuronide is the predominant pathway and accounts for over $90 \%$ of its metabolism $(155,156)$. Following conjugation of glucuronic acid to hymecromone, the resulting more hydrophilic metabolite, $4-\mathrm{MUG}$, is eliminated in the bile and urine (156). Biliary eliminated 4-MUG likely undergoes further enterohepatic recirculation with reabsorption of the metabolite from the intestine and ultimate elimination in the urine via the kidney. This is supported by a healthy volunteer pharmacokinetic study in which $93 \%$ of a single intravenous dose of hymecromone was eliminated as the 4-MUG metabolite in the urine (155). However, the precise contribution of enterohepatic recycling in the disposition of hymecromone and its metabolite is not well studied. 
Glucuronidation of hymecromone is catalyzed by the UGTs which are a large superfamily of over 20 proteins involved in the Phase II biotransformation of lipophilic xenobiotics and endogenous compounds $(157,158)$. UGTs are expressed in a wide range of tissues, however, for the purposes of drug biotransformation, the most clinically relevant are located in the liver and intestine $(159,160)$. Interestingly, hymecromone is a promiscuous molecule in that it is a substrate of most of the major hepatic and intestinal UGTs involved in drug metabolism (158). Consequently, the intestine and liver are very efficient in the metabolism of hymecromone. Pharmacokinetic studies in animals have demonstrated the extraction of hymecromone by the gastrointestinal system (pre-hepatic) to be $\sim 40 \%$ and extraction by the liver as high as $97 \%$ (156). As a result of this high extraction, the fraction of an administered oral dose of hymecromone that reaches the systemic circulation (posthepatic) as unchanged drug (i.e., the bioavailability) is very low. In a pharmacokinetic study of hymecromone in healthy volunteers, the systemic bioavailability of hymecromone after oral dosing was $<3 \%$ (155). As a treatment for biliary colic, the low bioavailability of hymecromone after an oral dose is less of a pharmacokinetic liability. Indeed, the high extraction by the liver may actually be beneficial as the drug is able to concentrate in the hepatic and biliary system.

If first-pass metabolism is bypassed by giving the dose IV, the systemic exposure achieved can be more than 10-30-fold higher than after the same dose given orally (155). However, due to the high clearance of hymecromone, systemic concentrations will decrease rapidly after an IV dose and peripheral exposures will likely be quite low by $4-6 \mathrm{~h}$ after a dose (apparent terminal half-life of $\sim 1 \mathrm{~h})$.

The pharmacokinetics of the hymecromone metabolite, 4MUG, are not well studied. In healthy volunteers, the systemic exposure of 4-MUG after an IV dose was shown to be higher than that of hymecromone (155). Pharmacokinetic data in humans after oral dosing on systemic exposure of 4-MUG are lacking. However, animal data from our group has demonstrated that the median plasma concentration of $4-\mathrm{MUG}$ compared to hymecromone was more than 3,000-fold higher in Balb/C mice on $5 \%$ oral hymecromone chow. This animal data highlights the potential importance of understanding 4-MUG pharmacokinetics during oral hymecromone therapy given the expected much higher exposures of the metabolite relative to the parent in peripheral tissues other than the intestine and liver. Future clinical studies of hymecromone in humans would benefit from a more thorough understanding of the pharmacokinetics of the 4-MUG metabolite including whether it is a potentially active moiety.

\section{THE THERAPEUTIC OUTLOOK FOR REPURPOSING HYMECROMONE}

The existing in vitro and in vivo data suggest that hymecromone may have utility as a component of therapeutic regimens directed against HA-producing cancers. There is less data at present to support this strategy in settings of chronic inflammation and autoimmunity but the potential is there as well. However, significant unresolved questions about safety, dosing, and mechanism remain.
While hymecromone has a long and relatively reassuring safety record, many questions remain about its potential repurposing for cancer treatment and other applications. These indications may require much higher dosages than those currently used to treat biliary spasm, introducing the potential for additional side effects. Certainly, the potent effects seen with 4-MU on tumor proliferation, angiogenesis, and migration could have detrimental effects on other tissues. There may also be unanticipated issues related to these novel applications. For example, in mouse models, 4-MU treatment has been linked to a reduced ability to renally excrete electrolytes and fluids (to diuresis) in response to rapid hydration (161). One could envision how this might be problematic if 4-MU were used in conjunction with chemotherapies that are renally cleared.

Long-term hymecromone treatment, rather than the more intermittent use associated with treatment of biliary spasm, might also be associated with unanticipated consequences. For example, we reported that 4-MU treatment was associated with worse atherosclerosis in ApoE-deficient mice fed a high-fat diet (104).

Several clinical pharmacology considerations must also be addressed. The large first-pass metabolism and rapid clearance of hymecromone are obstacles to achieving and maintaining high drug concentrations. This is particularly a concern in peripheral tissues (i.e., pancreas, skin, brain, etc.). Targeting conditions in the intestine and liver will pose less of a problem as these organs likely experience much higher exposures after oral dosing.

Understanding how experimental studies in animal models are likely to relate to human drug dose need and concentration is also likely to be important. Notably, the metabolism and drug disposition of 4-MU in mice may be very different than in humans.

Certainly the successful development of hymecromone will demand robust, pharmacokinetic studies of hymecromone and its metabolites in humans. Such detailed pharmacokinetic understanding will help develop dosing strategies including appropriate dose strength and frequency. These studies will set the stage for evaluation of this promising therapy in human clinical trials.

In summary, there is potential for hymecromone to be developed and repurposed as a safe, long-term adjunctive therapy for cancer treatment or other potential indication. Hymecromone's long and reassuring clinical track record, its oral route of delivery, and the exciting in vitro and in vivo data in mice all support further exploration of this therapeutic strategy. However, substantial pharmacologic and safety issues must be addressed in order to facilitate the translation of hymecromone into the clinic.

\section{ACKNOWLEDGMENTS}

This work was supported by the Deutsche Forschungsgemeinschaft (DFG) NA 965/2-1 (to NN); BRI Commercialization GAP funding Program grant (to TW and NN); and R01 DK096087-01 and U01 AI101984 (to PB). We gratefully acknowledge Virginia Green's help with preparation of this manuscript.

\section{REFERENCES}

1. Compston A, Coles A. Multiple sclerosis. Lancet (2002) 359:1221-31. doi:10. 1016/S0140-6736(02)08220-X

2. Jiang D, Liang J, Noble PW. Hyaluronan in tissue injury and repair. Annu Rev Cell Dev Biol (2007) 23:435-61. doi:10.1146/annurev.cellbio.23.090506.123337

3. Jiang D, Liang J, Noble PW. Hyaluronan as an immune regulator in human diseases. Physiol Rev (2011) 91:221-64. doi:10.1152/physrev.00052.2009 
4. Laurent TC, Laurent UB, Fraser JR. The structure and function of hyaluronan: an overview. Immunol Cell Biol (1996) 74:A1-7. doi:10.1038/icb.1996.32

5. Itano N, Atsumi F, Sawai T, Yamada Y, Miyaishi O, Senga T, et al. Abnormal accumulation of hyaluronan matrix diminishes contact inhibition of cell growth and promotes cell migration. Proc Natl Acad Sci U S A (2002) 99:3609-14. doi:10.1073/pnas.052026799

6. Fraser JR, Laurent TC, Pertoft H, Baxter E. Plasma clearance, tissue distribution and metabolism of hyaluronic acid injected intravenously in the rabbit. Biochem J (1981) 200:415-24.

7. Brown CT, Applebaum E, Banwatt R, Trinkaus-Randall V. Synthesis of stromal glycosaminoglycans in response to injury. J Cell Biochem (1995) 59:57-68. doi:10.1002/jcb. 240590108

8. Zakaria ER, Lofthouse J, Flessner MF. In vivo effects of hydrostatic pressure on interstitium of abdominal wall muscle. Am J Physiol (1999) 276:H517-29.

9. Stern R, Jedrzejas MJ. Hyaluronidases: their genomics, structures, and mechanisms of action. Chem Rev (2006) 106:818-39. doi:10.1021/cr050247k

10. Day AJ, de la Motte CA. Hyaluronan cross-linking: a protective mechanism in inflammation? Trends Immunol (2005) 26:637-43. doi:10.1016/j.it.2005.09.009

11. Day AJ, Prestwich GD. Hyaluronan-binding proteins: tying up the giant. J Biol Chem (2002) 277:4585-8. doi:10.1074/jbc.R100036200

12. Scott JE. Supramolecular organization of extracellular matrix glycosaminoglycans, in vitro and in the tissues. FASEB J (1992) 6:2639-45.

13. Tasanarong A, Khositseth S, Thitiarchakul S. The mechanism of increased vascular permeability in renal ischemic reperfusion injury: potential role of angiopoietin-1 and hyaluronan. J Med Assoc Thai (2009) 92:1150-8.

14. Khan AI, Kerfoot SM, Heit B, Liu L, Andonegui G, Ruffell B, et al. Role of CD44 and hyaluronan in neutrophil recruitment. J Immunol (2004) 173:7594-601. doi:10.4049/jimmunol.173.12.7594

15. Evanko SP, Potter-Perigo S, Bollyky PL, Nepom GT, Wight TN. Hyaluronan and versican in the control of human T-lymphocyte adhesion and migration. Matrix Biol (2012) 31:90-100. doi:10.1016/j.matbio.2011.10.004

16. Hascall VC, Majors AK, de la Motte CA, Evanko SP, Wang A, Drazba JA, et al. Intracellular hyaluronan: a new frontier for inflammation? Biochim Biophys Acta (2004) 1673:3-12. doi:10.1016/j.bbagen.2004.02.013

17. Gurtner GC, Werner S, Barrandon Y, Longaker MT. Wound repair and regeneration. Nature (2008) 453:314-21. doi:10.1038/nature07039

18. Ruppert SM, Hawn TR, Arrigoni A, Wight TN, Bollyky PL. Tissue integrity signals communicated by high-molecular weight hyaluronan and the resolution of inflammation. Immunol Res (2014) 58(2-3):186-92. doi:10.1007/s12026014-8495-2

19. Stern R, Asari AA, Sugahara KN. Hyaluronan fragments: an information-rich system. Eur J Cell Biol (2006) 85:699-715. doi:10.1016/j.ejcb.2006.05.009

20. Delmage JM, Powars DR, Jaynes PK, Allerton SE. The selective suppression of immunogenicity by hyaluronic acid. Ann Clin Lab Sci (1986) 16:303-10.

21. Neumann A, Schinzel R, Palm D, Riederer P, Münch G. High molecular weight hyaluronic acid inhibits advanced glycation end product-induced NFkappaB activation and cytokine expression. FEBS Lett (1999) 453:283-7. doi:10.1016/S0014-5793(99)00731-0

22. Forrester JV, Balazs EA. Inhibition of phagocytosis by high molecular weight hyaluronate. Immunology (1980) 40:435-46.

23. Jiang D, Liang J, Fan J, Yu S, Chen S, Luo Y, et al. Regulation of lung injury and repair by toll-like receptors and hyaluronan. Nat Med (2005) 11:1173-9. doi:10.1038/nm 1315

24. Campo GM, Avenoso A, Nastasi G, Micali A, Prestipino V, Vaccaro M, et al. Hyaluronan reduces inflammation in experimental arthritis by modulating TLR-2 and TLR-4 cartilage expression. Biochim Biophys Acta (2011) 1812:1170-81. doi:10.1016/j.bbadis.2011.06.006

25. Galeano M, Polito F, Bitto A, Irrera N, Campo GM, Avenoso A, et al. Systemic administration of high-molecular weight hyaluronan stimulates wound healing in genetically diabetic mice. Biochim Biophys Acta (2011) 1812:752-9. doi:10.1016/j.bbadis.2011.03.012

26. Hašová M, Crhák T, Safránková B, Dvoráková J, Muthný T, Velebný V, et al. Hyaluronan minimizes effects of UV irradiation on human keratinocytes. Arch Dermatol Res (2011) 303:277-84. doi:10.1007/s00403-011-1146-8

27. Huang P-M, Syrkina O, Yu L, Dedaj R, Zhao H, Shiedlin A, et al. High MW hyaluronan inhibits smoke inhalation-induced lung injury and improves survival. Respirology (2010) 15:1131-9. doi:10.1111/j.1440-1843. 2010.01829.x
28. Ye J, Wu H, Wu Y, Wang C, Zhang H, Shi X, et al. High molecular weight hyaluronan decreases oxidative DNA damage induced by EDTA in human corneal epithelial cells. Eye (Lond) (2012) 26:1012-20. doi:10.1038/eye.2012.89

29. Austin JW, Gilchrist C, Fehlings MG. High molecular weight hyaluronan reduces lipopolysaccharide mediated microglial activation. J Neurochem (2012) 122:344-55. doi:10.1111/j.1471-4159.2012.07789.x

30. Choi H, Lee RH, Bazhanov N, Oh JY, Prockop DJ. Anti-inflammatory protein TSG-6 secreted by activated MSCs attenuates zymosan-induced mouse peritonitis by decreasing TLR2/NF-B signaling in resident macrophages. Blood (2011) 118:330-8. doi:10.1182/blood-2010-12-327353

31. Kota DJ, Wiggins LL, Yoon N, Lee RH. TSG-6 produced by hMSCs delays the onset of autoimmune diabetes by suppressing Th1 development and enhancing tolerogenicity. Diabetes (2013) 62:2048-58. doi:10.2337/db12-0931

32. Powell JD, Horton MR. Threat matrix: low-molecular-weight hyaluronan (HA) as a danger signal. Immunol Res (2005) 31:207-18. doi:10.1385/IR:31:3:207

33. Tesar BM, Jiang D, Liang J, Palmer SM, Noble PW, Goldstein DR. The role of hyaluronan degradation products as innate alloimmune agonists. Am J Transplant (2006) 6:2622-35. doi:10.1111/j.1600-6143.2006.01537.x

34. Termeer C, Benedix F, Sleeman J, Fieber C, Voith U, Ahrens T, et al. Oligosaccharides of hyaluronan activate dendritic cells via toll-like receptor 4. J Exp Med (2002) 195:99-111. doi:10.1084/jem.20001858

35. Yamawaki H, Hirohata S, Miyoshi T, Takahashi K, Ogawa H, Shinohata R, et al. Hyaluronan receptors involved in cytokine induction in monocytes. Glycobiology (2008) 19:83-92. doi:10.1093/glycob/cwn109

36. de la Motte C, Nigro J, Vasanji A, Rho H, Kessler S, Bandyopadhyay S, et al. Platelet-derived hyaluronidase 2 cleaves hyaluronan into fragments that trigger monocyte-mediated production of proinflammatory cytokines. Am J Pathol (2009) 174:2254-64. doi:10.2353/ajpath.2009.080831

37. Campo GM, Avenoso A, Campo S, D’Ascola A, Nastasi G, Calatroni A. Small hyaluronan oligosaccharides induce inflammation by engaging both toll-like4 and CD44 receptors in human chondrocytes. Biochem Pharmacol (2010) 80:480-90. doi:10.1016/j.bcp.2010.04.024

38. Bollyky PL, Lord JD, Masewicz SA, Evanko SP, Buckner JH, Wight TN, et al. Cutting edge: high molecular weight hyaluronan promotes the suppressive effects of CD4+CD25+ regulatory T cells. J Immunol (2007) 179:744-7. doi:10.4049/jimmunol.179.2.744

39. Bollyky PL, Wu RP, Falk BA, Lord JD, Long SA, Preisinger A, et al. ECM components guide IL-10 producing regulatory T-cell (TR1) induction from effector memory T-cell precursors. Proc Natl Acad Sci U S A (2011) 108:7938-43. doi:10.1073/pnas.1017360108

40. McKee CM, Penno MB, Cowman M, Burdick MD, Strieter RM, Bao C, et al. Hyaluronan (HA) fragments induce chemokine gene expression in alveolar macrophages. The role of HA size and CD44. J Clin Invest (1996) 98:2403-13. doi:10.1172/JCI119054

41. Horton MR, Burdick MD, Strieter RM, Bao C, Noble PW. Regulation of hyaluronan-induced chemokine gene expression by IL-10 and IFN-gamma in mouse macrophages. J Immunol (1998) 160:3023-30.

42. Scheibner KA, Lutz MA, Boodoo S, Fenton MJ, Powell JD, Horton MR. Hyaluronan fragments act as an endogenous danger signal by engaging TLR2. J Immunol (2006) 177:1272-81. doi:10.4049/jimmunol.177.2.1272

43. Zheng L, Riehl TE, Stenson WF. Regulation of colonic epithelial repair in mice by toll-like receptors and hyaluronic acid. Gastroenterology (2009) 137:2041-51. doi:10.1053/j.gastro.2009.08.055

44. Gao F, Liu Y, He Y, Yang C, Wang Y, Shi X, et al. Hyaluronan oligosaccharides promote excisional wound healing through enhanced angiogenesis. Matrix Biol (2010) 29:107-16. doi:10.1016/j.matbio.2009.11.002

45. Gao F, Koenitzer JR, Tobolewski JM, Jiang D, Liang J, Noble PW, et al. Extracellular superoxide dismutase inhibits inflammation by preventing oxidative fragmentation of hyaluronan. J Biol Chem (2008) 283:6058-66. doi:10.1074/ jbc.M709273200

46. Mine S, Okada Y, Kawahara C, Tabata T, Tanaka Y. Serum hyaluronan concentration as a marker of angiopathy in patients with diabetes mellitus. Endocr J (2006) 53:761-6. doi:10.1507/endocrj.K05-119

47. Kang L, Lantier L, Kennedy A, Bonner JS, Mayes WH, Bracy DP, et al. Hyaluronan accumulates with high-fat feeding and contributes to insulin resistance. Diabetes (2013) 62:1888-96. doi:10.2337/db12-1502

48. Wong VS, Hughes V, Trull A, Wight DG, Petrik J, Alexander GJ. Serum hyaluronic acid is a useful marker of liver fibrosis in chronic hepatitis $\mathrm{C}$ 
virus infection. J Viral Hepat (1998) 5:187-92. doi:10.1046/j.1365-2893.1998. 00100.x

49. de la Motte CA. Hyaluronan in intestinal homeostasis and inflammation: implications for fibrosis. Am J Physiol Gastrointest Liver Physiol (2011) 301:G945-9. doi:10.1152/ajpgi.00063.2011

50. Cheng G, Swaidani S, Sharma M, Lauer ME, Hascall VC, Aronica MA. Hyaluronan deposition and correlation with inflammation in a murine ovalbumin model of asthma. Matrix Biol (2011) 30:126-34. doi:10.1016/j.matbio.2010. 12.003

51. Ayars AG, Altman LC, Potter-Perigo S, Radford K, Wight TN, Nair P. Sputum hyaluronan and versican in severe eosinophilic asthma. Int Arch Allergy Immunol (2013) 161:65-73. doi:10.1159/000343031

52. Liang J, Jiang D, Jung Y, Xie T, Ingram J, Church T, et al. Role of hyaluronan and hyaluronan-binding proteins in human asthma. J Allergy Clin Immunol (2011) 128:403-411.e3. doi:10.1016/j.jaci.2011.04.006

53. Wilkinson TS, Bressler SL, Evanko SP, Braun KR, Wight TN. Overexpression of hyaluronan synthases alters vascular smooth muscle cell phenotype and promotes monocyte adhesion. J Cell Physiol (2005) 206:378-85. doi: $10.1002 /$ jcp. 20468

54. Laurent TC, Laurent UB, Fraser JR. Serum hyaluronan as a disease marker. Ann Med (1996) 28:241-53. doi:10.3109/07853899609033126

55. Sakaguchi S, Miyara M, Costantino CM, Hafler DA. FOXP3+ regulatory T cells in the human immune system. Nat Rev Immunol (2010) 10:490-500. doi:10.1038/nri2785

56. Sutmuller RPM. Toll-like receptor 2 controls expansion and function of regulatory T cells. J Clin Invest (2005) 116:485-94. doi:10.1172/JCI25439DS1

57. Bogdani M, Johnson PY, Potter-Perigo S, Nagy N, Day AJ, Bollyky PL, et al. Hyaluronan and hyaluronan binding proteins accumulate in both human type 1 diabetic islets and lymphoid tissues and associate with inflammatory cells in insulitis. Diabetes (2014) 63(8):2727-43. doi:10.2337/db13-1658

58. Bollyky PL, Bogdani M, Bollyky JB, Hull RL, Wight TN. The role of hyaluronan and the extracellular matrix in islet inflammation and immune regulation. Curr Diab Rep (2012) 12:471-80. doi:10.1007/s11892-012-0297-0

59. Irving-Rodgers HF, Ziolkowski AF, Parish CR, Sado Y, Ninomiya Y, Simeonovic CJ, et al. Molecular composition of the peri-islet basement membrane in NOD mice: a barrier against destructive insulitis. Diabetologia (2008) 51:1680-8. doi:10.1007/s00125-008-1085-x

60. Hull RL, Johnson PY, Braun KR, Day AJ, Wight TN. Hyaluronan and hyaluronan binding proteins are normal components of mouse pancreatic islets and are differentially expressed by islet endocrine cell types. J Histochem Cytochem (2012) 60:749-60. doi:10.1369/0022155412457048

61. Bogdani M, Korpos E, Simeonovic CJ, Parish CR, Sorokin L, Wight TN. Extracellular matrix components in the pathogenesis of type 1 diabetes. Curr Diab Rep (2014) 14:552. doi:10.1007/s11892-014-0552-7

62. Bogdani M, Simeonovic C, Nagy N, Johnson PY, Chan CK, Wight TN. The detection of glycosaminoglycans in pancreatic islets and lymphoid tissues. Methods Mol Biol (2015) 1229:413-30. doi:10.1007/978-1-4939-1714-3_32

63. Back SA, Tuohy TMF, Chen H, Wallingford N, Craig A, Struve J, et al. Hyaluronan accumulates in demyelinated lesions and inhibits oligodendrocyte progenitor maturation. Nat Med (2005) 11:966-72. doi:10.1038/nm1279

64. Struve J, Maher PC, Li Y-Q, Kinney S, Fehlings MG, Kuntz C, et al. Disruption of the hyaluronan-based extracellular matrix in spinal cord promotes astrocyte proliferation. Glia (2005) 52:16-24. doi:10.1002/glia.20215

65. Winkler CW, Foster SC, Matsumoto SG, Preston MA, Xing R, Bebo BF, et al. Hyaluronan anchored to activated CD44 on central nervous system vascular endothelial cells promotes lymphocyte extravasation in experimental autoimmune encephalomyelitis. J Biol Chem (2012) 287:33237-51. doi:10.1074/jbc. M112.356287

66. Sloane JA, Batt C, Ma Y, Harris ZM, Trapp B, Vartanian T. Hyaluronan blocks oligodendrocyte progenitor maturation and remyelination through TLR2. Proc Natl Acad Sci U S A (2010) 107:11555-60. doi:10.1073/pnas.1006496107

67. Bugiani M, Postma N, Polder E, Dieleman N, Scheffer PG, Sim FJ, et al. Hyaluronan accumulation and arrested oligodendrocyte progenitor maturation in vanishing white matter disease. Brain (2013) 136:209-22. doi:10.1093/ brain/aws320

68. Asher R, Perides G, Vanderhaeghen JJ, Bignami A. Extracellular matrix of central nervous system white matter: demonstration of an hyaluronate-protein complex. J Neurosci Res (1991) 28:410-21. doi:10.1002/jnr.490280314
69. Cargill R, Kohama SG, Struve J, Su W, Banine F, Witkowski E, et al. Astrocytes in aged nonhuman primate brain gray matter synthesize excess hyaluronan. $\mathrm{Neu}$ robiol Aging (2012) 33:830.e13-24. doi:10.1016/j.neurobiolaging.2011.07.006

70. Yoshioka Y, Kozawa E, Urakawa H, Arai E, Futamura N, Zhuo L, et al. Suppression of hyaluronan synthesis alleviates inflammatory responses in murine arthritis and in human rheumatoid synovial fibroblasts. Arthritis Rheum (2013) 65:1160-70. doi:10.1002/art.37861

71. Majeed M, McQueen F, Yeoman S, McLean L. Relationship between serum hyaluronic acid level and disease activity in early rheumatoid arthritis. Ann Rheum Dis (2004) 63:1166-8. doi:10.1136/ard.2003.010942

72. Yung S, Chan TM. The role of hyaluronan and CD44 in the pathogenesis of lupus nephritis. Autoimmune Dis (2012) 2012:207190. doi:10.1155/2012/ 207190

73. Tishler M, Yaron I, Shirazi I, Yaron M. Salivary and serum hyaluronic acid concentrations in patients with Sjögren's syndrome. Ann Rheum Dis (1998) 57:506-8. doi:10.1136/ard.57.8.506

74. Gianoukakis AG, Jennings TA, King CS, Sheehan CE, Hoa N, Heldin P, et al. Hyaluronan accumulation in thyroid tissue: evidence for contributions from epithelial cells and fibroblasts. Endocrinology (2007) 148:54-62. doi:10.1210/en.2006-0736

75. Weiss L, Slavin S, Reich S, Cohen P, Shuster S, Stern R, et al. Induction of resistance to diabetes in non-obese diabetic mice by targeting CD44 with a specific monoclonal antibody. Proc Natl Acad Sci U S A (2000) 97:285-90. doi:10.1073/pnas.97.1.285

76. Naor D, Nedvetzki S, Walmsley M, Yayon A, Turley EA, Golan I, et al. CD44 involvement in autoimmune inflammations: the lesson to be learned from CD44-targeting by antibody or from knockout mice. Ann N Y Acad Sci (2007) 1110:233-47. doi:10.1196/annals.1423.025

77. Brocke S, Piercy C, Steinman L, Weissman IL, Veromaa T. Antibodies to CD44 and integrin alpha4, but not L-selectin, prevent central nervous system inflammation and experimental encephalomyelitis by blocking secondary leukocyte recruitment. Proc Natl Acad Sci U S A (1999) 96:6896-901. doi:10.1073/pnas. 96.12.6896

78. Howlett AR, Bissell MJ. The influence of tissue microenvironment (stroma and extracellular matrix) on the development and function of mammary epithelium. Epithelial Cell Biol (1993) 2:79-89.

79. Albini A, Sporn MB. The tumour microenvironment as a target for chemoprevention. Nat Rev Cancer (2007) 7:139-47. doi:10.1038/nrc2067

80. Ungefroren H, Sebens S, Seidl D, Lehnert H, Hass R. Interaction of tumor cells with the microenvironment. Cell Commun Signal (2011) 9:18. doi:10.1186/ 1478-811X-9-18

81. Lee JY, Spicer AP. Hyaluronan: a multifunctional, megaDalton, stealth molecule. Curr Opin Cell Biol (2000) 12:581-6. doi:10.1016/S0955-0674(00) 00135-6

82. Toole BP, Wight TN, Tammi MI. Hyaluronan-cell interactions in cancer and vascular disease. J Biol Chem (2002) 277:4593-6. doi:10.1074/jbc.R100039200

83. Turley EA, Noble PW, Bourguignon LYW. Signaling properties of hyaluronan receptors. J Biol Chem (2002) 277:4589-92. doi:10.1074/jbc.R100038200

84. Bourguignon LYW, Gilad E, Peyrollier K. Heregulin-mediated ErbB2-ERK signaling activates hyaluronan synthases leading to CD44-dependent ovarian tumor cell growth and migration. J Biol Chem (2007) 282:19426-41. doi:10.1074/jbc.M610054200

85. Li Y, Li L, Brown TJ, Heldin P. Silencing of hyaluronan synthase 2 suppresses the malignant phenotype of invasive breast cancer cells. Int J Cancer (2007) 120:2557-67. doi:10.1002/ijc.22550

86. Auvinen P, Rilla K, Tumelius R, Tammi M, Sironen R, Soini Y, et al. Hyaluronan synthases (HAS1-3) in stromal and malignant cells correlate with breast cancer grade and predict patient survival. Breast Cancer Res Treat (2014) 143:277-86. doi:10.1007/s10549-013-2804-7

87. Bullard KM, Kim H-R, Wheeler MA, Wilson CM, Neudauer CL, Simpson MA, et al. Hyaluronan synthase- 3 is upregulated in metastatic colon carcinoma cells and manipulation of expression alters matrix retention and cellular growth. Int J Cancer (2003) 107:739-46. doi:10.1002/ijc.11475

88. Simpson MA, Reiland J, Burger SR, Furcht LT, Spicer AP, Oegema TR, et al. Hyaluronan synthase elevation in metastatic prostate carcinoma cells correlates with hyaluronan surface retention, a prerequisite for rapid adhesion to bone marrow endothelial cells. J Biol Chem (2001) 276:17949-57. doi:10.1074/jbc.M010064200 
89. Entwistle J, Hall CL, Turley EA. HA receptors: regulators of signalling to the cytoskeleton. J Cell Biochem (1996) 61:569-77. doi:10.1002/(SICI)10974644(19960616)61:4<569::AID-JCB10>3.0.CO;2-B

90. Toole BP, Hascall VC. Hyaluronan and tumor growth. Am J Pathol (2002) 161:745-7. doi:10.1016/S0002-9440(10)64232-0

91. Rooney P, Kumar S, Ponting J, Wang M. The role of hyaluronan in tumour neovascularization (review). Int J Cancer (1995) 60:632-6. doi:10.1002/ijc. 2910600511

92. Slevin M, Krupinski J, Gaffney J, Matou S, West D, Delisser H, et al. Hyaluronanmediated angiogenesis in vascular disease: uncovering RHAMM and CD44 receptor signaling pathways. Matrix Biol (2007) 26:58-68. doi:10.1016/j. matbio.2006.08.261

93. Sironen RK, Tammi M, Tammi R, Auvinen PK, Anttila M, Kosma V-M. Hyaluronan in human malignancies. Exp Cell Res (2011) 317:383-91. doi:10. 1016/j.yexcr.2010.11.017

94. Tian X, Azpurua J, Hine C, Vaidya A, Myakishev-Rempel M, Ablaeva J, et al. High-molecular-mass hyaluronan mediates the cancer resistance of the naked mole rat. Nature (2013) 499(7458):346-9. doi:10.1038/nature12234

95. Karbownik MS, Pietras T, Szemraj J, Kowalczyk E, Nowak JZ. The ability of hyaluronan fragments to reverse the resistance of C6 rat glioma cell line to temozolomide and carmustine. Contemp Oncol (Pozn) (2014) 18:323-8. doi:10.5114/wo.2014.43493

96. Provenzano PP, Hingorani SR. Hyaluronan, fluid pressure, and stromal resistance in pancreas cancer. Br J Cancer (2013) 108:1-8. doi:10.1038/bjc.2012.569

97. Jacobetz MA, Chan DS, Neesse A, Bapiro TE, Cook N, Frese KK, et al. Hyaluronan impairs vascular function and drug delivery in a mouse model of pancreatic cancer. Gut (2013) 62:112-20. doi:10.1136/gutjnl-2012-302529

98. Baumgartner G. The impact of extracellular matrix on chemoresistance of solid tumors - experimental and clinical results of hyaluronidase as additive to cytostatic chemotherapy. Cancer Lett (1998) 131:1-2. doi:10.1016/S03043835(98)00204-3

99. Brown TJ. The development of hyaluronan as a drug transporter and excipient for chemotherapeutic drugs. Curr Pharm Biotechnol (2008) 9:253-60. doi:10.2174/138920108785161514

100. Gibbs P, Clingan PR, Ganju V, Strickland AH, Wong SS, Tebbutt NC, et al. Hyaluronan-irinotecan improves progression-free survival in 5-fluorouracil refractory patients with metastatic colorectal cancer: a randomized phase II trial. Cancer Chemother Pharmacol (2011) 67:153-63. doi:10.1007/s00280010-1303-3

101. Rilla K, Pasonen-Seppänen S, Rieppo J, Tammi M, Tammi R. The hyaluronan synthesis inhibitor 4-methylumbelliferone prevents keratinocyte activation and epidermal hyperproliferation induced by epidermal growth factor. J Invest Dermatol (2004) 123:708-14. doi:10.1111/j.0022-202X.2004.23409.x

102. Mahaffey CL, Mummert ME. Hyaluronan synthesis is required for IL-2mediated T cell proliferation. J Immunol (2007) 179:8191-9. doi:10.4049/ jimmunol.179.12.8191

103. García-Vilas JA, Quesada AR, Medina MÁ. 4-Methylumbelliferone inhibits angiogenesis in vitro and in vivo. J Agric Food Chem (2013) 61(17):4063-71. doi:10.1021/jf303062h

104. Nagy N, Freudenberger T, Melchior-Becker A, Rock K, Braak ter M, Jastrow $\mathrm{H}$, et al. Inhibition of hyaluronan synthesis accelerates murine atherosclerosis: novel insights into the role of hyaluronan synthesis. Circulation (2010) 122:2313-22. doi:10.1161/CIRCULATIONAHA.110.972653

105. Kultti A, Pasonen-Seppänen S, Jauhiainen M, Rilla KJ, Kärnä R, Pyöriä E, et al. 4-Methylumbelliferone inhibits hyaluronan synthesis by depletion of cellular UDP-glucuronic acid and downregulation of hyaluronan synthase 2 and 3. Exp Cell Res (2009) 315:1914-23. doi:10.1016/j.yexcr.2009.03.002

106. Kakizaki I, Kojima K, Takagaki K, Endo M, Kannagi R, Ito M, et al. A novel mechanism for the inhibition of hyaluronan biosynthesis by 4methylumbelliferone. J Biol Chem (2004) 279:33281-9. doi:10.1074/jbc. M405918200

107. Yoshihara S, Kon A, Kudo D, Nakazawa H, Kakizaki I, Sasaki M, et al. A hyaluronan synthase suppressor, 4-methylumbelliferone, inhibits liver metastasis of melanoma cells. FEBS Lett (2005) 579:2722-6. doi:10.1016/j.febslet. 2005.03.079

108. Bollyky PL, Evanko SP, Wu RP, Potter-Perigo S, Long SA, Kinsella B, et al. Th1 cytokines promote T-cell binding to antigen-presenting cells via enhanced hyaluronan production and accumulation at the immune synapse. Cell $\mathrm{Mol}$ Immunol (2010) 7:211-20. doi:10.1038/cmi.2010.9
109. Vigetti D, Ori M, Viola M, Genasetti A, Karousou E, Rizzi M, et al. Molecular cloning and characterization of UDP-glucose dehydrogenase from the amphibian Xenopus laevis and its involvement in hyaluronan synthesis. J Biol Chem (2006) 281:8254-63. doi:10.1074/jbc.M508516200

110. Vigetti D, Rizzi M, Viola M, Karousou E, Genasetti A, Clerici M, et al. The effects of 4-methylumbelliferone on hyaluronan synthesis, MMP2 activity, proliferation, and motility of human aortic smooth muscle cells. Glycobiology (2009) 19:537-46. doi:10.1093/glycob/cwp022

111. Clarkin CE, Allen S, Wheeler-Jones CP, Bastow ER, Pitsillides AA. Reduced chondrogenic matrix accumulation by 4-methylumbelliferone reveals the potential for selective targeting of UDP-glucose dehydrogenase. Matrix Biol (2011) 30:163-8. doi:10.1016/j.matbio.2011.01.002

112. Nakamura T, Funahashi M, Takagaki K, Munakata H, Tanaka K, Saito Y, et al. Effect of 4-methylumbelliferone on cell-free synthesis of hyaluronic acid. Biochem Mol Biol Int (1997) 43:263-8.

113. Nakazawa H, Yoshihara S, Kudo D, Morohashi H, Kakizaki I, Kon A, et al. 4-Methylumbelliferone, a hyaluronan synthase suppressor, enhances the anticancer activity of gemcitabine in human pancreatic cancer cells. Cancer Chemother Pharmacol (2006) 57:165-70. doi:10.1007/s00280-005-0016-5

114. Morohashi H, Kon A, Nakai M, Yamaguchi M, Kakizaki I, Yoshihara S, et al. Study of hyaluronan synthase inhibitor, 4-methylumbelliferone derivatives on human pancreatic cancer cell (KP1-NL). Biochem Biophys Res Commun (2006) 345:1454-9. doi:10.1016/j.bbrc.2006.05.037

115. Hajime M, Shuichi Y, Makoto N, Masanori Y, Ikuko K, Atsushi K, et al. Inhibitory effect of 4-methylesculetin on hyaluronan synthesis slows the development of human pancreatic cancer in vitro and in nude mice. Int J Cancer (2007) 120:2704-9. doi:10.1002/ijc.22349

116. Kudo D, Kon A, Yoshihara S, Kakizaki I, Sasaki M, Endo M, et al. Effect of a hyaluronan synthase suppressor, 4-methylumbelliferone, on B16F-10 melanoma cell adhesion and locomotion. Biochem Biophys Res Commun (2004) 321:783-7. doi:10.1016/j.bbrc.2004.07.041

117. Bhattacharyya SS, Paul S, Mandal SK, Banerjee A, Boujedaini N, Khuda-Bukhsh AR. A synthetic coumarin (4-methyl-7 hydroxy coumarin) has anti-cancer potentials against DMBA-induced skin cancer in mice. Eur J Pharmacol (2009) 614:128-36. doi:10.1016/j.ejphar.2009.04.015

118. Edward M, Quinn JA, Pasonen-Seppänen SM, McCann BA, Tammi RH. 4Methylumbelliferone inhibits tumour cell growth and the activation of stromal hyaluronan synthesis by melanoma cell-derived factors. Br J Dermatol (2010) 162:1224-32. doi:10.1111/j.1365-2133.2010.09699.x

119. Urakawa H, Nishida Y, Wasa J, Arai E, Zhuo L, Kimata K, et al. Inhibition of hyaluronan synthesis in breast cancer cells by 4-methylumbelliferone suppresses tumorigenicity in vitro and metastatic lesions of bone in vivo. Int J Cancer (2012) 130:454-66. doi:10.1002/ijc.26014

120. Saito T, Tamura D, Nakamura T, Makita Y, Ariyama H, Komiyama K, et al. 4Methylumbelliferone leads to growth arrest and apoptosis in canine mammary tumor cells. Oncol Rep (2013) 29:335-42. doi:10.3892/or.2012.2100

121. Saito T, Dai T, Asano R. The hyaluronan synthesis inhibitor 4methylumbelliferone exhibits antitumor effects against mesenchymal-like canine mammary tumor cells. Oncol Lett (2013) 5:1068-74. doi:10.3892/ol. 2013.1124

122. Piccioni F, Malvicini M, Garcia MG, Rodriguez A, Atorrasagasti C, Kippes N, et al. Antitumor effects of hyaluronic acid inhibitor 4-methylumbelliferone in an orthotopic hepatocellular carcinoma model in mice. Glycobiology (2012) 22:400-10. doi:10.1093/glycob/cwr158

123. Kundu B, Saha P, Datta K, Kundu SC. A silk fibroin based hepatocarcinoma model and the assessment of the drug response in hyaluronanbinding protein 1 overexpressed HepG2 cells. Biomaterials (2013) 34:9462-74. doi:10.1016/j.biomaterials.2013.08.047

124. Uchakina ON, Ban H, McKallip RJ. Targeting hyaluronic acid production for the treatment of leukemia: treatment with 4-methylumbelliferone leads to induction of MAPK-mediated apoptosis in K562 leukemia. Leuk Res (2013) 37(10):1294-301. doi:10.1016/j.leukres.2013.07.009

125. Lompardía SL, Papademetrio DL, Mascaró M, Álvarez EM, Hajos SE. Human leukemic cell lines synthesize hyaluronan to avoid senescence and resist chemotherapy. Glycobiology (2013) 23:1463-76. doi:10.1093/glycob/cwt074

126. Okuda H, Kobayashi A, Xia B, Watabe M, Pai SK, Hirota S, et al. Hyaluronan synthase HAS2 promotes tumor progression in bone by stimulating the interaction of breast cancer stem-like cells with macrophages and stromal cells. Cancer Res (2012) 72:537-47. doi:10.1158/0008-5472.CAN-11-1678 
127. Tamura R, Yokoyama Y, Yoshida H, Imaizumi T, Mizunuma H. 4Methylumbelliferone inhibits ovarian cancer growth by suppressing thymidine phosphorylase expression. J Ovarian Res (2014) 7:94. doi:10.1186/s13048-0140094-2

128. Arai E, Nishida Y, Wasa J, Urakawa H, Zhuo L, Kimata K, et al. Inhibition of hyaluronan retention by 4-methylumbelliferone suppresses osteosarcoma cells in vitro and lung metastasis in vivo. Br J Cancer (2011) 105:1839-49. doi:10.1038/bjc.2011.459

129. Twarock S, Freudenberger T, Poscher E, Dai G, Jannasch K, Dullin C, et al. Inhibition of oesophageal squamous cell carcinoma progression by in vivo targeting of hyaluronan synthesis. Mol Cancer (2011) 10:30. doi:10.1186/14764598-10-30

130. Colombaro V, Declèves A-E, Jadot I, Voisin V, Giordano L, Habsch I, et al. Inhibition of hyaluronan is protective against renal ischaemia-reperfusion injury. Nephrol Dial Transplant (2013) 28:2484-93. doi:10.1093/ndt/gft314

131. Forteza RM, Casalino-Matsuda SM, Falcon NS, Valencia Gattas M, Monzon ME. Hyaluronan and layilin mediate loss of airway epithelial barrier function induced by cigarette smoke by decreasing E-cadherin. J Biol Chem (2012) 287:42288-98. doi:10.1074/jbc.M112.387795

132. Sim M-O, Ham JR, Lee H-I, Seo K-I, Lee M-K. Long-term supplementation of umbelliferone and 4-methylumbelliferone alleviates high-fat diet induced hypertriglyceridemia and hyperglycemia in mice. Chem Biol Interact (2014) 216:9-16. doi:10.1016/j.cbi.2014.03.003

133. Mueller AM, Yoon BH, Sadiq SA. Inhibition of hyaluronan synthesis protects against central nervous system (CNS) autoimmunity and increases CXCL12 expression in the inflamed CNS. J Biol Chem (2014) 289:22888-99. doi:10.1074/jbc.M114.559583

134. Lokeshwar VB, Lopez LE, Munoz D, Chi A, Shirodkar SP, Lokeshwar $\mathrm{SD}$, et al. Antitumor activity of hyaluronic acid synthesis inhibitor 4methylumbelliferone in prostate cancer cells. Cancer Res (2010) 70:2613-23. doi:10.1158/0008-5472.CAN-09-3185

135. McKallip RJ, Hagele HF, Uchakina ON. Treatment with the hyaluronic acid synthesis inhibitor 4-methylumbelliferone suppresses SEB-induced lung inflammation. Toxins (Basel) (2013) 5:1814-26. doi:10.3390/toxins5101814

136. McKallip RJ, Ban H, Uchakina ON. Treatment with the hyaluronic acid synthesis inhibitor 4-methylumbelliferone suppresses lps-induced lung inflammation. Inflammation (2014). doi:10.1007/s10753-014-0092-y

137. Tofuku K, Yokouchi M, Murayama T, Minami S, Komiya S. HAS3-related hyaluronan enhances biological activities necessary for metastasis of osteosarcoma cells. Int J Oncol (2006) 29:175-83.

138. Hiraga T, Ito S, Nakamura H. Cancer stem-like cell marker CD44 promotes bone metastases by enhancing tumorigenicity, cell motility, and hyaluronan production. Cancer Res (2013) 73:4112-22. doi:10.1158/0008-5472.CAN12-3801

139. Vigetti D, Rizzi M, Moretto P, Deleonibus S, Dreyfuss JM, Karousou E, et al. Glycosaminoglycans and glucose prevent apoptosis in 4-methylumbelliferonetreated human aortic smooth muscle cells. J Biol Chem (2011) 286:34497-503. doi:10.1074/jbc.M111.266312

140. Kakizaki I, Takagaki K, Endo Y, Kudo D, Ikeya H, Miyoshi T, et al. Inhibition of hyaluronan synthesis in Streptococcus equi FM100 by 4-methylumbelliferone. Eur J Biochem (2002) 269:5066-75. doi:10.1046/j.1432-1033.2002.03217.x

141. Jong A, Wu C-H, Chen H-M, Luo F, Kwon-Chung KJ, Chang YC, et al. Identification and characterization of CPS1 as a hyaluronic acid synthase contributing to the pathogenesis of Cryptococcus neoformans infection. Eukaryot Cell (2007) 6:1486-96. doi:10.1128/EC.00120-07

142. Guan H, Nagarkatti PS, Nagarkatti M. Role of CD44 in the differentiation of Th1 and Th2 cells: CD44-deficiency enhances the development of Th2 effectors in response to sheep RBC and chicken ovalbumin. J Immunol (2009) 183:172-80. doi:10.4049/jimmunol.0802325

143. Ponta $\mathrm{H}$, Sherman L, Herrlich PA. CD44: from adhesion molecules to signalling regulators. Nat Rev Mol Cell Biol (2003) 4:33-45. doi:10.1038/nrm1004

144. Tanayama S, Kanai Y. Studies on increased bile formation produced by polyoxybenzenes in rats. Jpn J Pharmacol (1977) 27:71-8. doi:10.1254/jjp.27.71

145. Takeda S, Aburada M. The choleretic mechanism of coumarin compounds and phenolic compounds. J Pharmacobiodyn (1980) 4:724-34. doi:10.1248/ bpb1978.4.724

146. Fontaine L, Grand M, Molho D, Chabert MJ, Boschetti E. [Choleretic, spasmolytic and general pharmacologic activities of 4-methylumbelliferone]. Therapie (1968) 23:51-62.
147. Stacchino C, Spanò R, Pettiti A. Spasmolytic activity of some 4methylumbelliferone derivatives. Boll Chim Farm (1983) 122:158-60.

148. Abate A, Dimartino V, Spina P, Costa PL, Lombardo C, Santini A, et al. Hymecromone in the treatment of motor disorders of the bile ducts: a multicenter, double-blind, placebo-controlled clinical study. Drugs Exp Clin Res (2001) 27:223-31.

149. Camarri E, Marchettini G. [Hymecromone in the treatment of symptoms following surgery of the bile ducts]. Recenti Prog Med (1988) 79:198-202.

150. Krawzak HW, Heistermann HP, Andrejewski K, Hohlbach G. Postprandial bileduct kinetics under the influence of 4-methylumbelliferone (hymecromone). Int J Clin Pharmacol Ther (1994) 33:569-72.

151. Quaranta S, Rossetti S, Camarri E. [Double-blind clinical study on hymecromone and placebo in motor disorders of the bile ducts after cholecystectomy]. Clin Ter (1984) 108:513-7.

152. Trabucchi E, Baratti C, Centemero A, Zuin M, Rizzitelli E, Colombo R. Controlled study of the effects of tiropramide on biliary dyskinesia. Pharmatherapeutica (1986) 4:541-50.

153. Walter P, Seidel W. [Studies on the effect of 4-methyl-umbelliferon (Hymecromone) in patients following surgical revision of the biliary pathways]. Chirurg (1978) 50:436-40.

154. Hoffmann RM, Schwarz G, Pohl C, Ziegenhagen DJ, Kruis W. [Bile acidindependent effect of hymecromone on bile secretion and common bile duct motility]. Dtsch Med Wochenschr (2005) 130:1938-43. doi:10.1055/s-2005872606

155. Garrett ER, Venitz J. Comparisons of detections, stabilities, and kinetics of degradation of hymecromone and its glucuronide and sulfate metabolites. J Pharm Sci (1994) 83:115-6. doi:10.1002/jps.2600830128

156. Mulder GJ, Brouwer S, Weitering JG, Scholtens E, Pang KS. Glucuronidation and sulfation in the rat in vivo. The role of the liver and the intestine in the in vivo clearance of 4-methylumbelliferone. Biochem Pharmacol (1985) 34:1325-9. doi:10.1016/0006-2952(85)90513-1

157. Rowland A, Mackenzie PI, Miners JO. Transporter-mediated uptake of UDP-glucuronic acid by human liver microsomes: assay conditions, kinetics, and inhibition. Drug Metab Dispos (2015) 43:147-53. doi:10.1124/dmd.114. 060509

158. Uchaipichat V, Mackenzie PI, Guo X-H, Gardner-Stephen D, Galetin A, Houston JB, et al. Human UDP-glucuronosyltransferases: isoform selectivity and kinetics of 4-methylumbelliferone and 1-naphthol glucuronidation, effects of organic solvents, and inhibition by diclofenac and probenecid. Drug Metab Dispos (2004) 32:413-23. doi:10.1124/dmd.32.4.413

159. Rowland A, Miners JO, Mackenzie PI. The UDP-glucuronosyltransferases: their role in drug metabolism and detoxification. Int J Biochem Cell Biol (2013) 45:1121-32. doi:10.1016/j.biocel.2013.02.019

160. Guillemette C, Lévesque É, Rouleau M. Pharmacogenomics of human uridine diphospho-glucuronosyltransferases and clinical implications. Clin Pharmacol Ther (2014) 96:324-39. doi:10.1038/clpt.2014.126

161. Stridh S, Palm F, Hansell P. Inhibition of hyaluronan synthesis in rats reduces renal ability to excrete fluid and electrolytes during acute hydration. Ups J Med Sci (2013) 118:217-21. doi:10.3109/03009734.2013.834013

Conflict of Interest Statement: The authors declare that the research was conducted in the absence of any commercial or financial relationships that could be construed as a potential conflict of interest.

Received: 14 January 2015; accepted: 06 March 2015; published online: 23 March 2015. Citation: Nagy N, Kuipers HF, Frymoyer AR, Ishak HD, Bollyky JB, Wight TN and Bollyky PL (2015) 4-Methylumbelliferone treatment and hyaluronan inhibition as a therapeutic strategy in inflammation, autoimmunity, and cancer. Front. Immunol. 6:123. doi: 10.3389/fimmu.2015.00123

This article was submitted to Inflammation, a section of the journal Frontiers in Immunology.

Copyright (C) 2015 Nagy, Kuipers, Frymoyer, Ishak, Bollyky, Wight and Bollyky. This is an open-access article distributed under the terms of the Creative Commons Attribution License (CC BY). The use, distribution or reproduction in other forums is permitted, provided the original author(s) or licensor are credited and that the original publication in this journal is cited, in accordance with accepted academic practice. No use, distribution or reproduction is permitted which does not comply with these terms. 